\section{More demands on universities}

ENGINEERS on both sides of the Atlantic seem intent on getting a better deal for their profession. In the United States, one major battle has already been won now that the National Science Foundation has been convinced of the need to spend $\$ 10$ million a year on a network of university-based engineering centres to encourage interdisciplinary research and to bring academic engineers closer to industry (see below).

In Britain, the Engineering Council, the new and increasingly outspoken statutory body with responsibility for professional education and certification, wants more radical measures. The council this week announced that it wants to see an extra $£ 40$ million a year spent on engineering courses in universities and polytechnics, with a further $£ 200$ million in incentives to industrial companies to provide training places.

The council hopes for a 10 per cent swing in student numbers from arts-based to science-based subjects within the decade, with most of the extra going to engineering. (Some 15 per cent of British university students are studying engineering of some kind.) But, as engineering students cost twice as much to educate as arts students, the problem of money rears its ugly head. The council argues that shortages of trained engineers are constraining many British companies with interests in high tech-

\section{Hall back in favour}

BEIJING'S "Hall of Science" - a complex of more than $\mathbf{3 0}$ assembly and conference halls which was closed down during China's Cultural Revolution - was formally reopened last month.

The complex, established in 1963 under the patronage of Premier Zhou Enlai, at one time played a major role in the scientific life of the capital. The Red Guards, however, had condemned it on the grounds that it was a "Petofi club" - a term of abuse drawn from the "Petofi circles" of intellectuals in Hungary before the 1956 uprising.

Beijing scientists have been pressing for some time for the reopening of the Hall of Science. Last month's reinauguration was formally stated to have come about as a result of top-level party and state "attention" to the problem. Accordingly, Zhou Peiyuan, chairman of the China Science and Technology Association, reminded the 800 "elated" scientists at the reopening ceremony that their return to the complex was intended to help them "to accelerate development in the various branches of science, to pursue major scientific and technological subjects in the course of national economic construction and to serve the development of socialist material and spiritual civilization".

Vera Rich

nology, so that no price is too high. Its latest pronouncement is very much a political gesture: its goals will be out of reach unless the British Government is persuaded to put more resources into higher education than the omens suggest is likely. It is widely feared in the universities that a cut in government support by one per cent or more each year is now in prospect.

Many in the universities would accept this part of the argument, but the council has also risked losing academic friends by coming as close as it dared to accusing the universities of mismanagement of their funds. Sir Kenneth Corfield, the council's chairman, said that universities had to often used their recurrent grant to maintain the status quo rather than "in the way that was intended".

That view is not new to university vicechancellors, but it is the first time it has been stated so publicly. At least for the next

\section{US engineering education} five years, Sir Kenneth wants a proportion

\title{
Tripartite centres mooted
}

\section{Washington}

THE Reagan Administration seems to be pinning a great deal of hope for engineering education on a plan to establish engineering centres in close association with university engineering departments. The $\mathrm{Na}$ tional Science Foundation (NSF)'s draft budget for the next financial year includes a request for $£ 10$ million to launch the scheme, which has been applauded by a panel of the National Academy of Engineering. Meanwhile, NSF is working on the details of the scheme, when university departments will be invited to submit proposals.

Creation of the centres was proposed last year by NSF's engineering directorate in a working paper that argued that while much attention had been paid to the falling number of engineers prepared to work in universities, relatively little had focused on the quality of research produced by university engineers. In too many areas, it complained, industrial applications had outstripped the fundamental knowledge developed at universities. To keep pace, universities needed to foster research across the traditional sub-disciplines, and nurture closer contacts with large-scale engineering projects undertaken in industry.

In a report last month, the National Academy of Engineering endorsed the NSF scheme - with a vengeance. While conceding that NSF might have to begin by establishing fewer than ten centres in the first year, the academy wants NSF to aim eventually for a network of 25 centres, at an overall cost of at least $£ 100$ million. Engineering departments that want to join of the universities' recurrent grant to be earmarked for engineering by the University Grants Committee, presumably to stop the same thing happening in future. Universities, however, jealously guard their right to spend their grant as they wish. Mr Maurice Shock, vice-chancellor of the University of Leicester, said last week that he is "entirely opposed to the notion that a body can sit in London and dispose of the thousand and one considerations of individual universities"'.

The Engineering Council also wants more academics to take their sabbaticals in industry, and estimates that $£ 7$ million in earmarked funds is needed for the purpose. That idea is likely to be more acceptable to the universities and, as greater collaboration between universities and industry has been one of the most popular choruses of recent years, it might make some headway. The Committee of Vice-Chancellors and Principals has within the past month set up a committee to investigate the obstacles to collaboration; the transferability of pensions is one area likely to be scrutinized.

Tim Beardsley the new scheme should ensure that at least 10 per cent of their postgraduate engineering students and at least three full-time members of staff are involved in the centre.

Despite its enthusiasm, the academy has warned NSF that the centres should be seen as only one of several steps urgently needed to raise the standards of engineering research and education. Equally important are measures to lure talented engineers into university careers, an increase in the size of NSF research grants to engineers and replacement of outdated equipment. The academy also insists that the new emphasis on interdisciplinary research should not be allowed to impoverish fundamental disciplinary research.

NSF's handling of the new centres will be closely watched by an engineering community already critical of the foundation. Many university engineers maintain that NSF has paid insufficient attention to engineering, and a bill has been introduced in Congress to turn NSF into a National Science and Engineering Foundation. The bill would increase the number of engineering directorates at NSF and call on the foundation to sponsor applied research not yet ripe for industrial exploitation.

Dr Edward Knapp, NSF's director, has meanwhile been emphasizing the importance the foundation already places on engineering. In a recent speech at Duke University in North Carolina, he pointed out that half of the awards granted last year under NSF's new "young investigator" scheme were earmarked for engineers, and he promised that the same proportion would be designated under the expanded scheme in 1985.
Peter David 